Erzincan Üniversitesi Sosyal Bilimler Enstitüsü Dergisi 2020-13(2)-ss/pp.199-210

Erzincan University Journal of Social Sciences Institute

E-ISSN-2148-9289

\title{
Artin Hindoğlu'nun Grammaire De La Langue Turque İsimli Eseri Üzerine Bir Dil İncelemesi
}

\author{
An Examination on Artin Hindoğlu's Grammaire De La Langue Turque \\ Doç. Dr. Ali ÇİÇEK
}

Attf/C: Çiçek, Ali (2020). Artin Hindoğlu'nun Grammaire De La Langue Turque İsimli Eseri Üzerine Bir Dil İncelemesi, Erzincan Üniversitesi Sosyal Bilimler Enstitüsü Dergisi, Y11 13, Say1 2, ss. 199-210

Citation/(): Çiçek, Ali (2020). An Examination on Artin Hindoğlu's Grammaire De La Langue Turque, Erzincan University Journal of Social Sciences Institute, Year 13, Issue 2, pp. 215-226

\author{
Notlar/Notes \\ DOI: \\ 10.46790/erzisosbil.828474
}

Orcid:

0000-0003-3487-7794

\section{Ali Çiçek}

Erzincan Binali Yıldırım Üniversitesi Eğitim Fakültesi acicek@erzincan.edu.tr

Makale Türü-Article Type Araştırma/Research Derleme/Review

Geliş Tarihi-Received

2020-11-19

Kabul Tarihi-Accepted

2020-12-24

Sayfa-Pages

199-210

Yazar(lar), herhangi bir çıkar çatışması beyan etmemiştir.
Öz:

Bu çalışmada Artin HINNDOĞLU tarafindan 1829 tarihinde yazılan ve 1834 tarihinde de Fransizcaya aktarılan Grammaire Théorique et Pratique de la Langue Turke, Telle Qu'elle Est Parlée à Constantinople (İstanbul'da Konuşulmakta Olan Türkçenin Teorik ve Pratik Dilbilgisi) isimli eser ele alınmıştır. Kitabın Osmanlı Türkçesindeki adı ise Hazâ Kitâbu Sarf-1 Türkî'dir. Ön sözde, eser hakkında özet bilgi verilmiştir. Bu Türkçe dil bilgisi kitabı yedi bölüm ve özellikle fiil ağırlıklı bir Türkçe söz dizimin'den meydana gelmiş olup toplam VII+182 sayfadan ibarettir. Eserde, Türkçenin dil bilgisi daha çok uygulamalı bir şekilde işlenmeye çalışılmıştır. Yazar Türkçede yaygın olarak kullanılan kelime ve cümleleri ele almıştır.

Anahtar Kelimeler: Türkçe, Dil Bilgisi, Fiil, Harf, Fransızca.

\begin{abstract}
:
In this study, Grammaire Théorique et Pratique de la Langue Turke, Telle Qu'elle Est Parlée à Constantinople- (The Theoretical and Practical Grammar of Turkish Spoken in Istanbul), written by Artin HINNDOĞLU in 1829 and transferred to French in 1834, was adressed. The name of the book in Ottoman Turkish is Hazâ Kitâbu Sarf-1 Türkî. Fir. summary information about the work was given in foreword.This Turkish grammar book consists of seven chapters and especially a verb-based Turkish syntax part and consists of a total of VII +182 pages. In the work, the grammar of Turkish was tried to be dealt with in a more practical way. The author has dealt with the words and sentences commonly used in Turkish.
\end{abstract}

Keywords: Turkish, Grammar, Verb, Letter, French 


\section{GíRiş}

Bu yazıda, Viyana'da Türkçe dersleri veren Artin Hindoğlu'nun önce 1829 tarihinde Almanca olarak kaleme aldığı Osmanlı Türkçesini Anlama ve Konuşma Gramer Kitabı 12 Nisan 1834 tarihinde Fransızcaya aktarılarak, aynı tarihte Paris, Librairie Orientale de Prosper Dondey-Dupré yayınevinde " Grammaire Théorique et Pratique de la Langue Turke, Telle Qu'elle Est Parlée à Constantinople (İstanbul'da konuşulmakta olan Türkçenin Teorik ve Pratik Dilbilgisi) ismiyle kitap olarak bastırılmıştır. ${ }^{1} \mathrm{Bu}$ kitaba, Osmanlı Türkçesiyle de "Hazâ Kitâbu Sarf-ı Türkî” ismi verilmiştir. Türkçenin dil bilgisini esas alan bu Fransızca eser VII+182 sayfadan ibarettir. Ön sözünde ticari olmamak, yürürlükteki kanuni düzenlemelere bağlı kalınmak ve kaynak gösterilmek suretiyle bu kitaptan yararlanılabileceği kaydı bulunmaktadır.

Çeşitli kaynak incelemelerinde ve bilgisayar taramalarında bu eserin Türkçe tercümesine ulaşılamamıştır. Bunun yanında, Artin Hindoglu'nun Türkçeyle ilgili birkaç çalışması daha bulunmaktadır. Bunlardan en önemlisi, 1831 tarihinde Viyana'da basılan Dictionnaire abrégé Français-Turc (Hazine-i lûgat), isimli sözlüğüdür. Ayrıca Almanca-Ermenice-Türkçe, AlmancaTürkçe-Ermenice, Türkçe-Ermenice-Almanca isimli sözlükleri de kaleme almıştır.

Grammaire de la Langue Turque isimli bu eserin girişinde; Türkçede pek çok Arapça ve Farsça asıllı kelime ve terim bulunduğu ifade edilmiştir. Fransızca olarak kaleme alınan bu Türkçe dil bilgisi kitabının hazırlanmasında Türkçenin en meşhur diyalekti olan ve İstanbul'da seçkinlerce konuşulan ağzının esas alındığı belirtilmiştir. Yayımcı, İstanbul'da konuşulmakta olan Türkçenin yanında, Doğu ve Doğu Akdeniz'de yaygın olarak kullanılan idyomları ${ }^{2}$ da kapsayan pratik bir dil bilgisi kitabına acilen ihtiyaç duyulduğunu ifade etmiştir. Bu sebeple Artin Hindoğlu'nun önce Almanca olarak 1829 tarihinde Viyana'da yayımladığı Türk Dilinin Teorik ve Pratik Grameri kitabını ele aldıklarını belirtmiştir. Yayımcı, yazarın ön Asya'da doğması (1780, Kütahya) ve Türkçe ile Ermenice dillerini çok iyi bilmesi sebebiyle, onun Türkçenin dil bilgisini yazabileceği kanaatine vardıklarını ifade etmiştir. Böyle bir çalışma, Fransızların yanında Fransızca bilip de Türkçeyi öğrenmek isteyen Avrupalılar için de iyi bir fırsat olacaktı. Çünkü Avrupalıların Doğu'yla olan ilişkileri arttıkça bu bölgenin önde gelen dillerinden olan ve burada yoğun bir şekilde konuşulan Türkçenin öğrenilmesi gerekliydi. Bu sayede hem bu bölgeyi daha iyi tanımak, hem de ticari ilişkilerde ortaya çıkan iletişimi sağlamak için Türkçenin öğrenilmesine yardımcı olabilecek böyle kılavuz bir esere ihtiyaç vardı. Bu sebeple Türkçeyi açıklayan ve temel dil bilgisi özelliklerini anlatan bu kitap acilen basıldı. Yayımcı, yazarın bu eserde Türkçenin temel dil bilgisi yapılanmasını ve kurallarını ele alındığını ifade etmiştir.

Yayımcı, Hindoğlu'nun bu eserini yayımlamakla hem Fransız halkına ve hem de Fransızca bilen diğer Avrupa halklarına hizmet etmeye çalıştıklarını açıklamıştır.

Fransızca olarak kaleme alınan bu Türkçe dil bilgisi kitabı, önsözün dışında yedi bölüm ve bir söz dizimi (Fr. syntaxe) kısmından meydana gelmiştir.

\footnotetext{
1 Fransızca olarak kaleme alınan bu eser tarafımdan Türkçeye tercüme edildi, ancak henüz yayımlanamadı.

2 İdiome kelimesi, https://www.larousse.fr/dictionnaires/francais/idiome/41442' da “ Kimileri veya kimi topluluk tarafından kullanılan iletişim aracı, dil.” Tahsin SARAÇ’ın Büyük Fransızca-Türkçe Sözlük-Grand Dictionnaire Français-Turc isimli sözlüğünde “ 1. Deyim. 2. Bir topluluk yada ulusun konuştuğu dil.” olarak geçmekte, Dictionnaire Bordas 'da ise “ Bir ülkeye veya bölgeye ait dil, diyalekt.” şeklinde ifade edilmektedir. S. Sami’nin Kamus-i Fransevî’sinde ise, “ Bir kavmin lisân-1 mahsûsı, şîve-i lisânı, lugat, lehçe, bir lisanın bir eyalet veya bir kabileye mahsus fer'ı̂.” Bu açıklamaya, idyom kelimesinin Türkçede daha çok deyim karşılığı olarak kullanılmasından dolayı gerek duyulmuştur.
} 
Yazar, kitabın başından sonuna kadar Türkçenin kurallarını ve bu kuralların kullanışlarını açıklarken ele almış olduğu örneklerdeki kelimelerin, kelime gruplarının, konu gereği karşılaşılan yeni kelimelerin, yazılışlarını Arap harfleriyle, Türkçe okunuşlarını da Latin harfleriyle vermiştir. Ayrıca kelimelerin anlamlarını da, çoğunluğu parantez içinde olmak üzere ele almıştır. Bu çalışmada, kitapta bulunan bölümler sayfa aralıklarıyla gösterilmiş ve yerine göre bazı konular karşılaştırmalı bir biçimde açıklanmaya çalışılmıştır.

\section{I. BÖLÜM}

\subsection{Harf veya hurûf}

Bu bölümde (ss. 2-22) öncelikle o dönemde kullanılan alfabe (Fr. Alphabet Turk) ele alınmıştır. Önce Latin alfabesiyle harflerin isimleri (Fr. nom des lettres), yine harflerin Arap alfabesiyle başta, ortada ve sondaki yazılış şekilleri, ayrıca Latin alfabesiyle harflerin değerleri (Fr. valeur des lettres) ve telaffuz şekilleri tek tek verilmiştir. Bu açıklamalar üzerinde özenle durulduğu ve çokça örnek verildiği görülmektedir.

Yazar, Doğu'da kullanılan dillerin çoğunda olduğu gibi Türklerin de sağdan sola doğru yazılmakta olan yazı stilini kullandıklarını belirtmiştir. $O$ dönemde kullanılan Türk alfabesinin 28 harfinin Arapçadan, 3 harfinin de Farsçadan alındığı ifade edilerek bir tabloda sistematik bir biçimde verilmiştir (ss. 2-3). Ancak yazar lamelif i harf listesine dahil etmediği için toplam harf sayısı 33'tür.

Bu bilgilerin ardından, Türk ve Fransız harflerinin mukayeseli bir açıklaması verilmiştir (s. 4). Türkçe kelimeler önce Arap alfabesiyle yazılmış, parantez içerisinde de Latin alfabesiyle okunuşları verilmek suretiyle Türkçenin ses ve harf bakımından daha iyi ve daha pratik bir şekilde öğretilmesi amaçlanmıştır.

Yazar, eserinde Türk dilinin bazı kurallarını Fransız dil bilgisine göre ele almış, böylelikle Türkçeyi okurlarına daha kısa sürede ve daha pratik olarak öğretebilmenin anlayışı içinde olmuştur. O, öncelikle Türkçe kelimeleri orijinal kabul edilen karakterleriyle ele almış ve Meninski gibi telaffuzlarını da kaydetmiştir. Ancak ondan farklı olarak İstanbul ağzındaki telaffuz ve yazım biçimlerini de vermeye çalışmış ve bu sayede Türkçeyi daha doğru ve pratik biçimde öğretmek için kelimelerin telaffuzlarının önemli olduğu hususu üzerinde özenle durmuştur. Ona göre, bu dili öğreneceklerin Arap harfleriyle verilen telaffuzlarını da bilmeleri gerekmektedir. Önemli gördüğünden bu bölümü 22 sayfalık bir açıklama ile ele almıştır. Okumada diğer işaretler başlığı altında; üstün, esre, ötre'nin kullanış biçimlerini de vermiştir. Bunu yaparken de Fransız dilindeki harfler ile Türkçe karakterleri mukayeseli bir biçimde ele almıştır. Bunun için dönemin Türk alfabesindeki tüm harflerin seslendirilişini vermeye çalışmış, bu hususta Fransızcanın yetersiz kaldığı yerlerde Avrupa'nın değişik dillerinden, örneğin; İtalyancadan, Modern Yunancadan yararlanmıştır. Türk Alfabesindeki harflerin üstün, esre ve ötre almış kullanımlarını ve telaffuzlarını çok örnekli geniş açıklamalar hâlinde vermiştir.

Bilindiği gibi diller sesler üzerine kuruludur ve her dilin de kendine özgü bir ses sistemi vardır. Dolaysıyla dil öğretiminde seslerin doğru bir biçimde öğretilmesi önemlidir. Bu sebeple hedef dile ait ses yapısının iyi bilinmesi gerekir. Bu noktadan hareketle, yazarın bu hususta ele aldığı kelimeler ve cümleler ile Türkçenin ses yapısının öğretimine gerekli özeni gösterdiği anlaşılmaktadır. 
Ayrıca yazı çeşitleri başlığı altında Türklerin, Osmanlı Türkçesi döneminde; Kur'an-ı Kerim başta olmak üzere tarihî eserler, romanlar vb. eserleri kaleme almak için değişik yazı türlerini kullandıkları da ifade edilmiştir: nesih, sülüs, talik, divani, rika gibi.

\section{II. BÖLÜM}

\subsection{El-ism (Fr. nom)}

Bu bölümde (ss. 22-32) Türkçe isimlerden, isimlerin yapılarından bahsedilmektedir. Hindoğlu isimleri (el-ism) iki başlık altında ele almıştır: mevsûf (Fr. noms substantifs) veya nact yahut sıfat-ı zât (Fr. noms adjectifs). ${ }^{3}$ Yazar bu bölümde Türkçe sıfatların ${ }^{4}$ sayı, bükünlülük ve cinsliklerinin olmadığını ifade eder. Ayrıca o, isimleri adet (Fr. nombres) başlığı altında tekil (müfred) ve çoğul (cemî) olmak üzere de iki hâlde inceler. Türkçede çokluk eki -IAr'dır. Bazen de uygulamada -IAr çokluk eki yerine, Farsça -ân ve -hâ çokluk ekleri kullanılsa da bunlar sayılı birtakım kelimelerde görülmektedir: zen/ zenân (kadınlar), ejder/ ejdehâ (ejderhalar) gibi örnekler vermiştir.

Arapçadan gelmiş olan çokluk yapıdaki kelimeler, özellikle sözlü anlatımda teklik kelime gibi kullanılır: fukarâ/lar (fakirler), küberâ/lar (büyükler) gibi. Görüldüğü üzere Türkçe, yabancı dillerden geçen çokluk yapıdaki kelimelere de çokluk ekini (-IAr) ilave ederek kullanmaktadır. Yazar Arapçadan gelen ve cinsiyeti erkek olan bazı isimlerin sonuna he harfi eklemek suretiyle müennes (dişil) isim haline dönüştürüldüğünü de belirtmiştir. ${ }^{5}$ Türkçenin cinslik yapısıyla Fransızcanın bu konudaki durumu tamamen farklıdır. Mesela sultan kelimesinin erkek ve kadın için kullanımı aynıdır: Sultan Mahmut ve Sultan Fatime gününden kalma (s. 23) vb.

Yazar 26-31. sayfalar arasında Türkçedeki isim hâl eklerinin, sedalı ve sedasız ünsüzlerle biten tabanlara gelirken almış oldukları ekleri belirtmiş ve bu durumu da isimlerin sapması (Fr. déclination des noms ) olarak ele alıp çeşitli örnekler vermiştir: gün, günün, günden; kol, kolun, koldan vb. Fransızcada farklı bir biçimde ele alınan bu konuyu özenle işlemeye çalışmıştır. ${ }^{6}$ Ayrıca isimlerle ilgili sapmalara örnek olarak; isimlerin aldıkları son seslere göre yalın hâl (Fr. nominatif), ilgi hâli (Fr. genetif), yönelme hâli (Fr. datif), bulunma hâli (Fr. lokotif), uzaklaşma hâli (Fr. ablatif) ve diğer hâl ekleriyle isimlerin teklik ve çokluk biçimlerine ait açıklamalar yapılmıştır.

\footnotetext{
${ }^{3}$ Benzer ifadeleri Jean Deny de kullanmaktadır. s. 149

${ }^{4}$ Yazar burada isimlerden bahsederken sıfatları da konuya dâhil emektedir, bu şekildeki iç içe açıklamaları diğer bölümleri kaleme alırken de yapmıştır.

5 Bilindiği gibi Türkçede cinslik eki bulunmamaktadır. Bu hususta Muharrem ERGìN şunları söyler: "Türkçede gramatikal cinslik yoktur. Erkek ve dişi olan tabiî varlıkların erkeği ayrı, dişi ayrı isimler taşır. Bunlar hiçbir cinslik ifadesi olmayan tamamıyla müstakil isimlerdir. Erkek varlığın ismiyle dişi varlığın ismi arasında gramer bakımından hiçbir fark yoktur." Ancak bazı dillerde olduğu gibi cinslik yapısına sahip Fransızcada bu durum Türkçeden farklıdır: La femme est venuE (kadın geldi), l’homme est venu (erkek geldi), görüldüğü gibi özne olarak kullanılan kelimelerdeki cinslik farkı zaman çekimlerin çoğuna da aynen yansımaktadır.

${ }^{6}$ Türkçedeki hâl ekli yapılar ile Fransızcada bunları karşılayan yapılar arasında çok önemli farklar olduğundan yazar bu konuyu özenle ele almıştır: Türkçede buna isimlerin sapmaları değil, isimlerin hâl ekli yapılarla çekimleri denilmektedir ve bu durum sabit bir dil bilgisi yapısıdır.
} 


\section{III. BÖLÜM}

\subsection{Sifatlar (Fr. adjectifs)}

Kitabın III. bölümünde (s. 32-43) sıfatların yapıları ve kullanımları ele alınmıştır. Yazar, Türkçede sıfatların büyük bir kısmının isimlerden meydana geldiğini, yerine göre isimlerin -II, $I U$ ve diğer birtakım ekler almak veya geçişli fiillerin şimdiki zamanın 3. tekliğini de kullanmak suretiyle sıfat elde edilebileceğini ifade etmiştir. ${ }^{7}$ Karşılaştırmaya dayalı olarak sıfat gibi kullanılan kelimelerin mevcut olduğunu ifade edilmiştir: -ca, -ce ekiyle güzelce, -rak/-rek ekiyle alçakrak, küçürek ${ }^{8}$ vb. daha pek çok ekle sıfat yapıldığı kaydedilmiştir. Ancak yazarın sıfatlarla ilgili yaptığı sınıflandırma ve açıklamalarda bazı kullanım sorunları vardır. Örneğin; ism-i tasgir (Fr. diminutif) başlığı altında ele aldığı avretcik ( Fr. petite femme), köpekçik ( Fr. le petit chien) vb. ${ }^{9}$ kelimelerin yazımlarını vermiştir. Fakat yazarın örnek verdiği bu kelimelerden bazıları kullanılmamaktadır.

Ayrıca yazar, bu bölümde iyelik isimleri (ism-i mensûb, Fr. noms possessifs) konusunu ele alırken Fransızcadaki yapılanmayı öne çıkarmıştır: at-lu, et-lü, akıl-lu vb. Ayrıca şehir, yer, ülke isimlerinden türeme sıfatlar da bu başlığa dahil edilmişlerdir: Kara Denizlü, Bosnalu, Macarlu gibi. İsimden isim yapım eki olan $+I I /+I U$ eki; sahiplik görevinde kendinde bulundurma, bir yere veya bir şeye bağlılık ve mensubiyet için kullanılmakta olup büyük çoğunlukla sıfat yapmaktadır. Türkçede iyelik şekli, isim çekim eklerinden olan iyelik ekleriyle yapılmaktadır. Ayrıca iyelik ve mensubiyet farklıdır, zaten Türkçede, Fransızcada olduğu gibi bir iyelik yapısı da yoktur. Yine bu bölümde Türkçe kelimeleri türlerine göre kök (câmid) ve türeme (müştak) olarak da ikiye ayrmıştır.

\section{IV. BÖLÜM}

\subsection{Sayı isimleri (esmâü'l-aded)}

Bu bölümde (s. 44-53) sayı isimleri (esmâü'l-aded) ele alınmıştır. Örnek olarak ele alınan kelimelerin Türkçe karşılıklarının yanında Arapça ve Farsça karşılıkları da birlikte verilmiştir. Bazı alanlarda sayıların ifadesinde Farsça sayı isimlerinden yararlanılır; tavla oyununda kullanılan zar isimleri buna dahildir. Yazar, Türkçede sayı isimlerinin rahat bir biçimde kullanıldığını ifade eder: yarım saat, saat yarım, çeyrek saat vb. Sıra sayıları da Arapça ve Farsça karşılıklarıyla birlikte verilmiştir. Kitap bölümlerinin numaralandırılmasında Arapça sıra sayı isimlerinden, bazen de Farsça sayılardan yararlanılmıştır.

\section{V. BÖLÜM}

\subsection{Zamir ( Fr. pronoms )}

Yazar, bu bölümünde (s. 53-68) zamirleri ele almış ve bunları okuyucusuna daha iyi kavratabilmek için yalın, ilgi, yönelme, yükleme, bulunma ve çıkma durumlarını kapsayan

\footnotetext{
7 Sıfat-fiil konusu bazı benzerliklerine rağmen Türkçe ve Fransızcada farklı şekillerde ele alınmaktadır: Fransızcada yalnızca şimdiki zaman 3. Teklik şahıs eki atılır, kalan kısma -ant eki getirilmek suretiyle yapılırken, Türkçenin zengin bir sıfat-fiil yapısı vardır.

${ }^{8}$ Zeynep KORKMAZ, bu konuyu,“" Sifatlarda Karşılaştırma ve Derecelendirme İşlevi” başlı̆̆ı altında ele almıştır. (Z. KORMAZ, s. 370-397.

${ }^{9} \mathrm{Bu}$ kelimeler Türkçe kelime yapma sisteminde bulunmalarına rağmen, kullanım alanında çok seyrek olarak yer almaktadırlar. Türkçe Sözlük'e ve Kamus-i Türkî’ye bakılabilir.
} 
çekimleri altı şahsa göre ve detaylı bir şekilde vermiştir. Ayrıca açıklamasında dönüşlük zamirinin şahıslara göre çekim ve kullanımıyla ilgili birçok örnek bulunmaktadır. Eserde Türkçedeki bağlama zamiri terimine karşılık olarak ilgi zamiri (Fr. pronom relatif) ifadesi kullanılmıştır. ${ }^{10}$ ilgi zamiri olarak ki'nin bazen kim şeklinde kullanıldığı ifade edilmiş, konuyla ilgili örnekler verilmiştir. Bunun yanında hangi, nesi, kim, neleri, kangı ( kangı ev, hangisi geldi) vb. soru zamirlerin de bahsedilmiştir.

Yazar, iyelik zamirlerini ${ }^{11}$, iyeliklerin Fransızcadaki kullanışlarını öne çıkararak açıklamıştır: benim ( mon), senin (ton), onun (son), bizim (notre), sizin (votre), anların (leur). Ayrıca bu şahıs çekimlerine ki'yi ilave ederek; benimki (le mien), seninki (le tien), anınki (le sien), bizimki (le nôtre), sizinki (le vôtre), anlarınki (le leur) vb. biçimlerini de açıklamıştır. Fransızca, şahıslara ait iyelik sıfatlarını ve iyelik zamirlerini ayrı ayrı ve çekimsiz kelimelerle karşıladığından bu konuda Türkçeden farklı bir yapılanma içindedir. Örnek; benim babam (mon père: mon iyelik sıfatıdır), benimki (le mien/la mienne iyelik zamiri) vb. Yazar, aynı şekilde iyelik zamirlerinin hâl ekli çekimlerini de vermiştir.

\section{VI. BÖLÜM}

\subsection{Fiil (Fr. verbes)}

Bu bölümde (s. 68-138) Türkçedeki fiillerin yapıları ve kullanımları ele alınmıştır. Bu bölüm için ayrılan sayfa aralığına bakıldığında, diğer bölümlere göre fiiller üzerinde daha çok durulduğu görülmektedir. Yazar, Türkçe fiil yapısının iyi anlaşılabilmesi için işe emir çekiminden başlamak ve diğer zamanların çekimini yapabilmek için de köke şahıs ve zaman ekleri ilave etmek gerektiğini ifade etmiştir. Bu açıklamalar i-mek isim-fiili hariç Türkçenin fiil yapısına uygundur. ${ }^{12}$ Türkçe fiillerin öğretilmesinde yazar kendince hızlı ve pratik bir yol takip etmiştir: Kitapta, fiil kökü tespit edildikten sonra zaman çekimleri ele alınarak önce, $-r,-A r$ ekiyle geniş zaman, $-d l /-t l$, ekiyle görülen geçmiş zaman, $-s A$ ekiyle de şart biçimi çekimlenmiştir. ${ }^{13}$ Yazar konuyu pratik olarak ele aldığı için fiilden fiil yapım eklerini, fiilden isim yapım eklerini ve fiil çekim eklerini bir arada vermiştir: -mak/-mek, -ış/-iş, -l-, -dır-/-dir-, vb. Ancak filleri, bu şekilde açıklamak sistematik olmadığı gibi birtakım karışıklıklara da sebep olmaktadır.

Yazar, fiillerin olumsuz çekimini verirken şu iki şekli ele almıştır:

Olumsuz (Fr. négatif) şekil: sevmemek

İmkânsız (Fr. impossible) şekil: sevememek (ne pas pouvoir aimer) ${ }^{14}$.

\footnotetext{
10 Bu konuda Fransızcadaki pronom relatif yapısı Türkçeye göre birtakım farklılıklar göstermektedir. ( G. Mauger, Grammaire parlée de la langue pratique du français d'aujourd'hui langue écrite, s. 163-173).

${ }^{11}$ Türkçede iyelik çekimlerine karşı Fransızcada her şahıs için kullanılan ayrı ayrı iyelik yapısı vardır.

${ }^{12}$ Bu hususta M. Ergin'in açıklamalarına bakılabilir. (M. Ergin, Edebiyat ve Eğitim Fakültelerinin Türk Dili ve Edebiyatı Bölümleri İçin Türk Dil Bilgisi s.267)

${ }^{13}$ Fransızcada müstakilen kullanılan geniş zaman yoktur, şimdiki zaman (Fr. présent de l'indicatif) geniş zamanı da karşılar. (G. Mauger, Cours de Langue et de Civilisation Françaises II, s. 266).

${ }^{14}$ Bu terimle ilgili olarak Jean DENY (DENY J. (1941) Türk Dili Grameri (Osmanlı Lehçesi ), Ter. Ali Ulvi ELOVE, Maarif Matbaas1, İstanbul ,. s. 356.) menfi iktidar terimini kullanmaktadır ki bu da Hindoğlu'nun kullandığı ifadeye yakındır.
} 
Eserinde bu konuyla ilgili pek çok örnek verilmiştir. Ancak yapabilmek ve yapamamak fiilleri muktedir olmayı veya olmamayı ifade etmektedirler, imkânsızlık kavramı ise kesinlik belirttiğinden bu başlık altında ele alınmamalıdır.

Bu bölümde isimden fiil yapan eklerden bazılarıyla ilgili bilgi verilirken Türkçede durumu hâlen tartışılan bir şekilcilik öne çıkmıştır: -lamak/-lemek, yarı-lamak, yaldız-lamak; gecelemek (gicelemek), mühürlemek (möhürlemek), domuz (doñuz)-lanmak ${ }^{15} \mathrm{vb}$.

Yazar sıfatlardan türetilen fillere; güzellenmek, derinlenmek, derinlendirmek, bilmezlenmek, görmezlenmek yapılarını örnek olarak vermiştir.

Eserde yardımcı fiiller etken ve edilgen olarak iki başlık altında ele alınmıştır: etmek, eylemek, kılmak, olunmak, kılınmak vb. Ayrıca bu yardımc fiillerin isimlerle birlikte kullanışlarına örnekler verilmiştir; (s. 81): zahir ol-, zuhur et- gibi birleşik fiiller kullanılmıştır.

Yazar, yardımcı fiillerin çekimi başlığı altında isim fiilinin (i-mek) çekimini vermiştir. Onun, ek fiili temel yardımcı fiil olarak isimlendirmesi Fransızcadaki olmak (être) fiilinin anlam ve kullanımından ileri gelmektedir. Bu fiil Fransızcada temel iki yardımcı fiilden biri olup tüm zamanlarda çekilebildiği için i-mek fiilinden farklıdır. Bu durum göz önüne alınmadığından $i-$ mek fiilinin çekiminde zorlamalar bulunmaktadır. Ayrıca yazar, isim fiilinin zarf-fiil ve partisip şekillerinden (-imiş, idi, ise) de bahsetmiştir. ${ }^{16}$ Ancak bu değerlendirmelerden bazıları isimfiilinin Türkçe yapısıyla uyuşmamaktadır.

Yazar Türkçedeki sahip olmak / malik olmak fiilin açıklamasında (Fr. avoir) iyeliği daha vurgulu şekilde ifade etmek ve Fransızcanın cümle yapısına uygun hâle getirmek, böylece yabancılar açısından öğrenilmesini kolaylaştırmak için benim akçem var yerine benim var akçem biçiminde açıklayıcı cümleler kullanmıştır. Ayrıca bu fiilin hikâye birleşik zamanı, şart kipi ve diğer zaman çekimlerini de vermiştir.

Aynı şekilde olmak yardımcı fiilinin (Fr. verbe auxiliaire: être) şimdiki zamanı ${ }^{17}$ Türkçeye geniş zaman karşılığı olarak da tercüme edilmektedir. Bu ol- yardımcı fiilinin tüm zaman çekimlerinin Türkçe karşılıkları verilmiş, ancak bu çekimlerden bazılarını, birtakım Fransızca kaynaklara göre farklı şekilde ele almıştır. ${ }^{18}$

Gelecek zamanın Türkçede beş ayrı şekilde çekimlendiği ifade edilmiştir:

1.Geniş zaman ile olurum (Fr. je deviendrai). 2. Gelecek zaman olacağım ( Fr. je deviendrai). 3. İstek kipi ile olalar ( Fr. ils deviendront). 4. Gereklilik kipi ile olmalu (Fr. il doit devenir). 5. Şart kipi ile olsa ( Fr. il doit devenir) ${ }^{19}$. Kitapta, bu hususla ilgili Türkçedeki çekimler Fransızca

\footnotetext{
${ }^{15} \mathrm{Bu}$ kelimenin kök kısmı Tarama Sözlüğünde doñuz (toñuz) olarak geçmektedir. Ancak yazarın kullandığ toñuzlanmak fiili gerek Tarama Sözlük’ünde bulunmamaktadır.

${ }^{16} \mathrm{Bu}$ konuyla ilgili olarak Muharrem. ERGINN, "Bütün bu partisip ekleri içinde $i$ - fiili yalnız -dük ekini alır: $i$ $d \ddot{u g}-i$ şeklinde görüldüğ̈ gibi. $i$ - kişiye ait bu tek partisibi eskiden daha çok kullanılırdı. Bugün de klişeleşmiş olarak yaşamaktadır: ne idügi belirsiz misalinde olduğu gibi.”(s. 319) şeklinde tespitte bulunmuştur.

${ }^{17}$ Fransız gramerindeki présent de l'indicatif zamanı Türkçeye şimdiki zaman ve geniş zaman olarak tercüme edilmektedir.

${ }^{18}$ Gerek G. Mauger, gerek Jean Deny’de zamanların isimlendirilişi ve tasnifi konusunda A. HİNDOĞLU'dan kısmen de olsa farklı düşünmektedirler.

${ }^{19}$ Türkçede, gelecek zaman çekimiyle ilgili şekil yönünden böyle bir sıralama yoktur. Ancak anlam ve kapsam olarak Yazarın bu konudaki görüşlerine yaklaşan bazı tespitleri, kiplerde zaman kaymaları adı altında görmekteyiz. Zeynep KORKMAZ, s. 596-646.
} 
karşılıklarıyla verilmiş, kısa açıklamalar yapılmıştır. Fakat bilindiği üzere tasarlama kipleri şekil özelliklerine karşın, açık ve kesin bir zaman ifade etme özelliği taşımazlar ${ }^{20}$.

Emir biçimiyle ilgili 2. teklik ol, 3. teklik olsun, 1. çokluk olalım, 2. çokluk olun, olunuz, 3. çokluk olsunlar kullanımları verilmiştir. Yani yazara göre Türkçede 1. Teklik şahıs hariç diğer 5 şahıs için emir çekimi var demektir. Bilindiği üzere, Türkçede emir çekiminin kaç şahıstan ibaret olduğu hususunda Türk dilbilimcileri arasında da görüş ayrılıkları bulunmaktadır.

\subsection{Ekleme}

Yazar, fiil bölümü kapsamındaki bu ekleme kısmında, fiillerin meydana getirilmesi (Fr. formation des verbes) konusunu ele alarak fiilden fiil yapma eklerini ayrı bir başlık altında değil de, kullanıma bağlı olarak dağınık bir şekilde açıklamıştır. Bunu da, Türkçe fiilleri daha pratik öğretme arzusuyla tercih ettiğini örneklerle göstermiştir. Ancak bunun, birtakım karışıklıklara sebep olabileceği de ortadır. Bilindiği üzere Türkçede asıl pasiflik ve meçhullük ekleri -n-, -I'dir. -l- ise çok işlek bir fiilden fiil yapım ekidir. Bu yapı Fransızcada, Türkçeden farklı olup kelimeler aracılığıyla yapılmaktadır. Bu da bize, Türkçe fiillerin üretim ve kullanımlarının Fransızcadakilerden çok daha pratik olduğunu göstermektedir. Yazarın bu konuyla ilgili verdiği örneklerden birkaçı: sevilmek, bakılmak ( Fr. être aimé, être vu), Ancak o, bunun istisnası olarak kök ve gövdenin ünlüyle bitmesi halinde - $n$ - ekinin kullanıldığını, konuşmada ise yine I- ekinin tercih edildiğini ifade etmiştir: denmek, denilmek vb. Ayrıca -t-, -ş-, -r-, vb. diğer fiilden fiil yapım eklerini de birçok örnekle açıklamıştır.

Yazara göre Türklerin kullandığı fiiller genelde kişilere aittir. Ancak kişisiz yapılar da ( Fr. modes impersonnels) mevcuttur: vardır, gerektir, denir, nakl olunur vb.

\section{VII. BÖLÜM}

El-hurûf ( Fr. des autres parties du discours)

Bu bölümde zarflardan, bağlaçlardan, edatlardan vb. bahsedilmektedir. ${ }^{21}$

\subsection{Zarf}

Yazar zarfları, fiillerin sıfatı (Fr. adjectif verbe) olarak tanımlamaktadır. O, zarfları Türkçe asıllı olanlar, Arapçadan ve Farsçadan alınanlar ele almış ve birçok örnek vererek açıklamıştır. Yazar, zarfları; nitelik, nicelik, yer, zaman, istek, tasdik, sayı, sıra, küçültme, dilek, uyarı, karşı koyma, korkutma, azlık, övgü, selamlama, şüphe, mukayese, birleştirme, ayrıştırma vb. alt başlıklarıyla ele almış ve uzunca açıklamalar yapmıştır.

\subsection{Edat}

$\mathrm{Bu}$ kısımda Türkçede kullanılmakta olan edatlardan bazıları ele alırken istisnai durumlardan da bahsedilmiştir. Örneğin; isimlerden sonra rahat bir şekilde gelebilmeleri: ev içre, baş üzere, dağ aşırı vb.

\footnotetext{
${ }^{20}$ Bu hususta Tahsin BANGUOĞLU ( Türkçenin Grameri, s. 443) ve Z. KORKMAZ’ın (Türkiye Türkçesi, Türkiye Türkçesi Grameri s. 647) eserlerine bakılabilir.

${ }^{21}$ Yazarın burada kelime türlerini açıklamak için kullandığg discours kelimesinin Türkçede kabul gören karşılığı "söylem”dir, bu da ki dil arasındaki anlamlandırma farklılığından kaynaklanmaktadır.
} 


\subsection{Bağlaç}

Yazar, bağlaçların sık kullanılanları ele alarak ayırma, zıtlık, açıklama ve şart, sonuç, istisna, susturma, beğenme vb. bildirenleri ayrı başlıklar hâlinde örnekler vermek suretiyle açıklamıştır.

Türkçe sözdizimi ( Fr. Syntaxe Turke)

$\mathrm{Bu}$ bölümde Türkçe cümle yapısı ve cümlenin kullanımıyla ilgili bazı açıklamalar verilmiştir. Yazara göre; Türkler günlük hayatta birine hitap ederken büyük çoğunlukla 2. teklik şahsı, üst düzey biriyle konuşuluyorsa 2. çokluk şahsı kullanılmaktadırlar. Oldukça yüksek bir mevkide bulunanlarla konuşuluyorsa cenapları, hazretleri hitaplarının yanında hazretin, hazretiniz, padişah hazretleri, paşa hazretleri vb. kalıp ifadeleri kullanılmaktadır. Ayrıca kibarlık bildirmek için 1. teklik şahıs yerine biz, saygısını belirtmek için bendeniz, kulunuz, köleniz, hizmetkârınız, fakirhânemiz vb. hitaplar geçerli olmaktadır. Ayrıca Türkçede yerine göre ev yerine fakirhâne (Fr. la pauvre maison), eşim yerine halayığınız, kulunuz, ehlim; halk ağzında karım, avradım. ${ }^{22}$ gibi kullanışlar mevcuttur.

Yazar, Türk dilinde yüklemin cümlenin sonunda bulunduğunu ifade eder. Ancak konuşma dilinde durum farklı olabilmektedir: Var götür o akçeyi. vb. Yazar, burada fiillerin dizimi (Fr. syntaxe des verbes) çekimli halleriyle cümle içerisindeki görevlerini, aldıkları hâl eklerini ve edatlarla kullanımlarını örneklerle açıklamıştır.

\section{SONUÇ}

Yukarıdaki açıklamalardan hareketle şunu belirtmek gerekir ki; yabancıların gerek önceki dönemlerde, gerekse günümüzde Türk dil bilgisini esas alan eserler yazmaları, Türkçenin kurallarına bağlı kaldıkları müddetçe dilimiz açısından hem bir kazanç, hem de övünülecek bir husustur. Türkçenin bir dünya dili olarak karşılık görmesi ve üzerinde bu tür çalışmalar yapılmış olması Türkçe severlerin ve bu dili konuşanların öncelikli beklentileridir. Ancak bu çalışmalar Türkçeye tercüme edilirken tenkitli şerhlerinin de yapılması büyük bir önem arz etmektedir. Çünkü Türkçenin dil bilgisini ele alan yabancı yazarlar, farkında olarak veya olmayarak kendi dillerinin bazı kurallarını dilimize aktarabilmektedirler. Bu, bazen tercüme yapandan da kaynaklanabilmektedir. Türkçenin dil bilgisinin esaslarına uymayan bu tür alıntılar sebebiyle dilimizde, özellikle kurallar açısından hâlen gündemde olan birtakım tartışmalar mevcuttur. Bu tartışmaların merkezini daha çok kavram karışıklıkları meydana getirmektedir.

Bu kitabın girişinde yayımcl; eserin yazıldığı dönemde kamunun, bir yabancı dil olarak Türkçeyi öğrenmeye yardımcı olacak pratik dil bilgisi kitaplarının hazırlanmasını istediğini beyan etmiştir. Dolaysıyla yabancılar için Türkçe kitapları hazırlanırken dilin gramer özellikleri sağlam kaynaklardan alınarak pratik bir biçimde ortaya konulmalıdır. Çünkü katı gramer kurallarının hâkim olduğu dil bilgisi kitapları, en azından bu eserin hazırlanmasında, pratik dil öğretimi için tercih edilmemiştir.

\footnotetext{
22 Yazar karım ve avradım kelimeleri için ( ma femme ve ma concubine) kelimelerini kullanmıştır. Ancak concubin,e kelimesine evlilik dışı nikahsız yaşayan kadın, erkek (Petit Larousse) karşılığı verilmiştir. Ayrıca bu kelimeye; aralarında hiçbir kanuni bağ olmadan bir erkekle birlikte yaşayan kadın (Dictionnaire du français vivant, Bordas) anlamı yüklenmiş, Kamus-i Fransevî’de ise odalık, müstefreşe anlamında kullanılmıştır. Tahsin SARAÇ bu kelime için nikâhsız (karı ya da koca) karşılı̆̆ını vermiştir.
} 
Bu kitabın, bilimsel bir amaçtan çok, Avrupalıların Osmanlı Devleti'nin hükümran olduğu yerlerdeki ticarî, sosyal, kültürel vb. ilişkilerini daha rahat bir biçimde yürütmelerine yardımcı olmak için kaleme aldığını görülmektedir.

Konular verilirken Türk grameri esas alınmış, ancak Fransızcanın dil kurallarından da yararlanılmıştır. Örneğin, iyelikler konusunda Fransızcadaki iyelik sıfatları ve iyelik zamirlerinden de bahsedilmiş, konuyla ilgili açıklamalar bu şekilde yapılmıştır. Bu ve benzeri kural aktarmaları Türkçede birtakım sorunlara ve tartışmalara sebep olabilmektedir.

Türkçe dil kavramları, Fransızcanın imkânları dâhilinde açıklanmış, yetersiz kalındığında bazı Avrupa dillerinden de yararlanılmıştır. Bu durum, Türkçeye yapılacak farklı alanlardaki tercüme çalışmaları için de geçerli olabileceğinden, bu husus gözden uzak tutulmamalıdır.

Bölümler arasında kurulan ilgilerin ve yerine göre farklı konuların bir arada verilmeye çalışılması, bazen konuların iç içe girmesine sebep olmuştur. Bunun da kısa zamanda çok şey öğretme düşüncesinden kaynaklandığı anlaşılmaktadır. Bunun pratik dil öğretimindeki olumlu ve olumsuz yanları tartışılabilir.

Eserin önsözünde yayımcı, böyle bir eseri yayımlamakla Fransız halkına hizmet ettiklerini ifade etmiştir. Her ne sebeple olursa olsun, bu bize Türkçenin o dönemde aranılan ve ihtiyaç duyulan önemli bir dil olduğunu göstermektedir.

$\mathrm{Bu}$ eserin meydan getirilmesinde yazarın kullandığı örneklerdeki kelimelerin, kelime gruplarının vb. unsurlarının yazım ve telaffuzları, dönemin Türkçesindeki ses ve yapı hususiyetlerini göstermesi bakımından önemli olup bu alanda çalışacaklara da katkılar sağlayabilir.

Dillerin birbirlerinin söz varlıklarını, anlatım güçlerini, iletişim ve kültürel etkileşimlerini, görmek ve birtakım çıkarımlar yapmak için bu tür çalışmalara ihtiyaç vardır. 


\section{REFERENCES/ KAYNAKÇA}

DEVELLioĞLU, F. (2012). Osmanlıca-Türkçe Ansiklopedik Lûgat, 29. Bas., Aydın Kitabevi Yay., Ankara.

ERGiN, M. (1993). Edebiyat ve Eğitim Fakültelerinin Türk Dili ve Edebiyatı Bölümler Için Türk Dil Bilgisi, 21. Bas., Bayrak Yay., İstanbul.

MAUGER, G. (1968). Grammaire pratique et du français d'aujourd'hui langue parlée langue écrite, septième édition revue, Librairie Hachette, Paris

https://www.larousse.fr/dictionnaires/francais/idiome/41442

DENY, J. (1941). Türk Dili Grameri (Osmanlı Lehçesi ), Ter. Ali Ulvi ELOVE, Maarif Matbaası, İstanbul.

KORKMAZ, Z. (2003). Türkiye Türkçesi Grameri (Şekil Bilgisi), TDK, Ankara,

Maurice, Davau- Morcel Kohen-Maurice Lallemand. (1972). Dictionnaire du français vivant, Bordas, Bruxelles,.

SARAÇ, T. (1990). Büyük Fransızca-Türkçe Sözlük-Grand Dictionnaire Français-Turc, Adam Yay., 3. Bas. İstanbul.

ŞEMSEDDiN, S. (1898). Kamûs-i Fransevî Dictionnaire Français-Turc, 2. Baskı, Mihran Matbaası, İstanbul.

ŞEMSEDDiN, S.. (1998). Kamûs-i Türkî, Alfa Yay., İstanbul.

BANGUOĞLU, T. (1998).Türkçenin Grameri TDK Yayınları: 528, Ankara.

Tarama Sözlüğü, (1996). 2. Bas., TDK Yay., Ankara.

TiMURTAŞ. F.K. (1999). Tarihî Türkiye Türkçesi Araştırmaları Osmanlı Türkçesi Grameri III, 14. Baskı, Alfa Yay.,

Türkçe Sözlük, (2010). TDK, Ankara, 


\section{EXTENDED SUMMARY}

In this study, Grammaire Théorique et Pratique de la Langue Turke, Telle Qu'elle Est Parlée à Constantinople (The Theoretical and Practical Grammar of Turkish Spoken in Istanbul) written by Artin HINDOĞLU in German in 1829 and transferred to French in 1834 was discussed. The name of the book in Ottoman Turkish is Hazâ Kitâbu Sarf-1 Türkî. In the introduction of the work, it was stated that the most famous dialect of Turkish, spoken by the breed apart in Istanbul, was taken as basis in the preparation of this Turkish grammar book and brief information about the work was given.

The publisher stated that they came to the conclusion that the author was born in Asia Minor (1780, Kütahya) and knew the Turkish and Armenian languages very well, so he could write the grammar of Turkish. The publisher of the book, by publishing this work of Hindoğlu, in the geography dominated by the Ottoman Empire, commercial, cultural, etc. he explained that they were trying to serve French people who had relations and other European businessmen who spoke French, and those who wanted to get to know this region. This Turkish grammar book consists of seven chapters and especially a verb-based Turkish syntax and consists of a total of VII + 182 pages. In the work, the grammar of Turkish has been studied in a more applied way.

In the first part of the book, which consists of 22 pages, the Turkish letters and the pronunciation of the letters used in that period were mentioned, and the sound structure of Turkish was carefully emphasized by giving many examples. The author also made use of the French grammar rules while explaining the subjects in both this section and other sections, and also made use of Italian and different languages of Europe, especially Modern Greek, in these matters where French was insufficient. In addition, under the title of script types, explanations were made about the types of writing used by the Turks during the Ottoman Turkish period such as naskh, sulus, talik, divani, rika.

Names and structures of nouns in Turkish were discussed in the second chapter, noun suffixes and their usages were explained with examples, and important explanations were made especially with the introduction of the -1Ar plural suffix to foreign words in Turkish. The author, who divided the third part of his book into adjectives, stated that most of the adjectives in Turkish consist of nouns. While the possessive (ism-i mensûb, Fr. noms possessifs) is given in Turkish only, some of the explanations have been confused with the possessive structure in French. In Chapter 4, numeral adjectives are given with the title of numeral names (esmâüladed).

In chapter 5 of the book, pronouns are mentioned in detail. However, although some explanations do not fit the possessive conjugation of Turkish, the examples given are correct. As in some of the above mentioned explanations, the operations of possessive pronouns have been tried to be explained by considering their usage in French. In Turkish, possessives are added to the name with an inflectional suffix, while possessive structures in French are made up of words.

In the 6th chapter, the structures and usages of verbs in Turkish are discussed extensively. 70 pages of the book are devoted to this section. Verbs roof, main and auxiliary verbs, tenses, etc. It has been discussed, and explanations that can be considered original according to the period are given regarding the future tense shooting. On the other hand, in the 7th chapter under the title of El-hurûf (Fr. des autres parties du discours), the subjects of adverb, preposition and conjunction were discussed and various examples were given. 